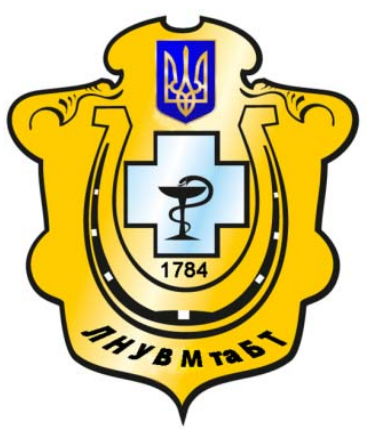

Науковий вісник Львівського національного університету ветеринарної медицини та біотехнологій імені С.3. Гжицького

Scientific Messenger of Lviv National University of Veterinary Medicine and Biotechnologies named after S.Z. Gzhytskyj

doi:10.15421/nvlvet6932

ISSN 2413-5550 print

ISSN 2518-1327 online

http://nvlvet.com.ua/

УДК 338.43:551.4.012

\title{
Семасіологічний зміст методу в наукових дослідженнях
}

\author{
Н.Ю. Фіщук \\ natalfis@rambler.ru
}

Вінницький національний аграрний університет, вул. Сонячна, 3, м. Вінниця, 21008, Украӥна

Констатуються розбіжності в розумінні поняття «методи» та їх класифікаиії, чим зумовлюється актуальність означеної проблеми.

Розглядаються методи як атрибут будь-якої людської діяльності та їх багатоальтернативність. Наводяться численні приклади тлумачення поняття «методи дослідження», визначається та аналізується семасіологічний зміст поняття «метод» в контексті наукових досліджень на основі словниково-енциклопедичних видань, наукових публікацій та навчальних посібників. Припускається біпарний зміст методів дослідження. Зроблена спроба трактування цього поняття з позицій практичної роботи дослідника, тобто як явища, з одного боку, та з позичій теорії - як наукової категорії, з іншого. $B$ першому випадку методи дослідження знаходяться у безпосередньому зв'язку з функиіональними елементами змісту дослідження. При виконанні дипломних робіт пропонується використання класифікації методів, яка рекомендована для дисертаційних досліджень. 3 огляду на неоднозначність трактування методів дослідження та їх класифікації в наукових публікаціях, аргументується необхідність подальшого вивчення проблеми класифікачії методів дослідження.

Ключові слова: методи, способи, інтерпретачія, класифікаиія, закони, приниипи, дипломна робота, наукова категорія, явище.

\section{Семасиологическое содержание метода в научных исследованиях}

\author{
Н.Ю. Фищук \\ natalfis@rambler.ru
}

Винницкий национальный аграрный университет,

ул. Солнечная, 3, г. Винница, 21008, Украина

Констатируются различия в понимании понятия «методы» и их классификаџии, чем обуславливается актуальность данной проблемьл.

Рассматривается метод как атрибут любой человеческой деятельности. Анализируется содержание понятия «метод» в контексте научных исследований на материалах словарно-энщиклопедических изданий, научных публикаций и учебных пособий. Сделана попытка трактовать это понятие, во-первых, с точки зрения практической деятельности исследователя, то есть как явления, и во-вторых, с точки зрения теории, как научной категории. В прочессе исполнения дипломных работ предлагается использование классификации методов, которая рекомендуется для диссертационных исследований.

Учитывая неоднозначность трактовки методов исследования и их классификачии в научных публикациях, аргументируется необходимость дальнейшего изучения проблемы классификачии методов исследования.

Ключевые слова: методы, способы, интерпретация, классификация, законы, принципы, дипломная работа, научная категория, явление.

\section{Citation:}

Fischuk, N. (2016). Semasiological content of method in scientific researches. Scientific Messenger LNUVMBT named after S.Z. Gzhytskyj, 18, 2(69), $165-168$. 


\title{
Semasiological content of method in scientific researches
}

\author{
N. Fischuk \\ natalfis@rambler.ru \\ Vinnitsa National Agrarian University, \\ Soniachna Str.,3, Vinnytsya, 21008, Ukraine
}

\begin{abstract}
Differences in the understanding of the concept of «methods» and their classification, that predetermines the relevance of the problem, are ascertained.

Methods as an attribute of any human activity and their multiversions are studied. Numerous examples of the interpretation of the term «methods of research» are given, semasiological concept of «method» in the context of scientific researches on the basis of dictionaries, encyclopaedias, scientific publications and tutorials is defined and analysed.

Binary content of research methods is assumed. The attempt of interpretation of this concept from the standpoint of practical work of the researcher, which means studying it as a phenomenon, on the one hand, and from the standpoint of theory, which means studying it as scientific category, on another hand, is made. In the first case, the methods are in direct connection with the functional elements of the study content. The method classification that is recommended for dissertation researches is offered to use while working on graduate work.

The necessity of further study of the problem of classification of research methods is demonstrated because of ambiguity of the interpretation of research methods and their classification in scientific publications.

Key words: methods, ways, interpretation, classification, laws, principles, graduate work, scientific category, phenomenon.
\end{abstract}

\section{Вступ}

У відповідності до галузевих стандартів вищої освіти студенти готують і захищають магістерські та дипломні роботи, в яких мають бути елементи наукової новизни. Тому, обравши тему, студент мусить проводити конкретні дослідження певними методами. Студенти-дипломники і їхні керівники при проведенні досліджень та оформленні їх результатів зустрічаються 3 деякими негараздами щодо використання методів дослідження. Ці негаразди породжені розбіжностями в розумінні поняття «методи» та їх класифікації. Даною обставиною і зумовлюється актуальність означеної проблеми.

Сучасні наукові публікації і навчальні посібники, що присвячені організації наукових досліджень, засвідчують різні позиції їх авторів щодо трактування змісту поняття «методи». Суттєвий внесок в опрацювання місця і ролі методів в контексті наукових досліджень зробили вітчизняні науковці. Серед них: Андрійчук В.Г. (Andriichuk, 2016), Ганін B.I. (Ganin et al., 2008), Єрмаков О.Ю. (Iermakov et al., 2009), Кандиба А.M. (Kandyba, 2007), Клименко М.O. (Klymenko et al., 2010), Крушельницька О.В. (Krushelnytska, 2009), Мочерний С.В. (Mochernyi, 2001), Сурмін Ю.П. (Surmin, 2006), Цехмістрова Г.С. (Tsekhmistrova, 2003), Гальчинський A.C. (Galchynskyi, 2010). Таке багатозначне трактування методу вимагає поглибленого дослідження цього феномену в науці.

Мета статті - уточнити і поглибити зміст поняття «методи дослідження» в контексті підготовки дипломних та магістерських робіт.

\section{Результати та їх обговорення}

Звичайні спостереження за сферою людської діяльності свідчать про те, що в ній завжди мають місце численні методи (табл.1).

Матеріали таблиці 1 дають підстави стверджувати, що методи є атрибутом всіх видів людської діяльності, по-перше, i, по-друге, що вони багатоальтернативні.

Щоб з'ясувати семасіологічний зміст слова «метод», звернемось до авторитетних словниковоенциклопедичних видань:

1) «спосіб пізнання явищ природи та суспільного життя» (Slipushko, 2007);

2) «прийом або система прийомів, що застосовуються в якій-небудь галузі діяльності (науці, виробництві тощо)» (Slipushko, 2007);

3) «спосіб досягнення якої-небудь мети, розв'язання конкретного завдання» (Prokhorov, 1983);

4) «сукупність прийомів або операцій практичного або теоретичного освоєння (пізнання) дійсності» (Prokhorov, 1983);

5) «спосіб пізнання явищ природи та суспільного життя»... (Kovaliova, 2005);

6) «прийом або система прийомів, що застосовуються у якій-небудь галузі діяльності (науці, виробництві тощо )» (Kovaliova, 2005).

На основі матеріалів таблиці 1 та словникових джерел можна стверджувати, що метод, як явище в практичній діяльності людей, є способом виконання конкретної дії, операції чи роботи. Значення терміну «метод» в наукових дослідженнях має свої особливості і досить неоднозначно тлумачиться різними авторами. Так, в праці «Майстерня вченого» Ю.П.Сурміна наводяться наступні визначення:

1) «...діяльність, спрямована на об’єкт 3 метою одержання знань про нього.»;

2) «...правильний шлях, засіб досягнення будьякої мети...»;

3) «...засіб пізнання, спосіб відтворення дійсності в нашій свідомості.»;

4) «...система принципів та правил практичної i теоретичної діяльності.»;

5) «...сукупність систематизованих пізнавальних операцій...»; 
6) «...сукупність пізнавальних процесів.»;

7) «...сукупність відносно рівнозначних операцій.»;

8) «...система дій 3 досягнення поставлених цілей...»;

9) «...сукупність принципів, процедур і конкретних методик.»;

10)«...форма зв’язку дослідника з об'єктом дослідження.»;

11) «...засіб вдосконалення і розвитку знань.»;

12)«...один 3 інтеграційних механізмів науки.»

Методи діяльності в різних сферах суспільної практики

\begin{tabular}{|c|l|}
\hline Види діяльності & \multicolumn{1}{c|}{ Методи виконання } \\
\hline Навчання у ВНЗ з опанування знаннями з дисциплін & $\begin{array}{l}\text { лекція, } \\
\text { практичне заняття, } \\
\text { лабораторне заняття, } \\
\text { семінарське заняття, } \\
\text { самостійна робота студентів }\end{array}$ \\
\hline Реалізація товарів & $\begin{array}{l}\text { прямий оптовий збут, } \\
\text { збут через посередників, } \\
\text { роздрібна торгівля }\end{array}$ \\
\hline Лікування хворих людей & терапевтичне, \\
& хірургічне, \\
& психологічне \\
\hline Виробництв матеріальних благ & індивідуальне \\
& серійне, \\
& масове \\
\hline Долання відстані & велосипед, \\
& пояя, \\
& автомобіль, \\
літак \\
\hline Написання тексту & олівцем, \\
& ручкою, \\
& комп’ютерним набором \\
\hline Наукове дослідження & спостереження, \\
& моделювання, \\
& аналіз і синтез, \\
& експеримент \\
\hline
\end{tabular}

(Surmin, 2006).

Різноманітні інтерпретації змісту поняття «методи дослідження» пропонуються читачеві рядом авторів (Mochernyi, 2001; Kandyba, 2007; Ganin et al., 2008; Iermakov et al., 2009; Krushelnytska, 2009; Klymenko et al., 2010; Galchynskyi, 2010; Andriichuk, 2016).

Складність усвідомлення поняття «метод» зумовлюється тим фактом, що воно неоднозначно тлумачиться різними авторами.
Табличя 1
Джерело: складено автором

Ретельний аналіз літературних джерел та матеріали особистих досліджень стосовно методів у сфері наукової діяльності дають підстави стверджувати, що методи дослідження як явище - це дії, операції і роботи на шляху до виявлення нових знань. Стосовно дослідження за темою дипломної чи магістерської роботи також використовуються конкретні методи у відповідності до функціонального (процесуального) змісту самого дослідження. Мається на увазі те, що дослідження $є$ складною інтегрованою функцією i воно складається $з$ конкретних підфункцій, а саме:

- усвідомлення потреби і формулювання проблеми;

- обрання об'єкта;

- виділення в об'єкті предмета дослідження;

- визначення мети дослідження;

- опрацювання вузлових і робочих завдань;

- складання плану (змісту) дипломної роботи;

- виконання плану;

- формулювання висновків (результатів дослідження);

- оформлення додатків;

- упарюдкування списку використаних джерел;
- оформлення повного тексту дипломної роботи в переплетеному вигляді.

Кожна 3 перелічених підфункцій потребує своїх рухів, дій, операцій чи робіт як методів виконання. Самою об'ємною і складною підфункцією в щойно перерахованому наборі $\epsilon$ виконання плану дослідження, де кожний його пункт реалізується за допомогою методів, притаманних його змісту.

Неоднозначність трактування методів дослідження породжує і різні варіанти їх класифікаційних груп. При виконанні дипломної роботи доцільно використовувати класифікацію методів, яка рекомендується для дисертаційних досліджень (рис.1).

Будь-яка людська свідома ефективна діяльність узгоджується із законами та принципами (правилами), в яких конкретизуються вимоги законів. Якщо в нашому розумінні методи дослідження на практиці $€$ способами виконання дій, операцій і робіт, то вони теж регламентуються законами і принципами, з одного боку. 3 іншого боку методи визначають, вимагають, приписують, диктують, як саме належить діяти в конкретних ситуаціях. 


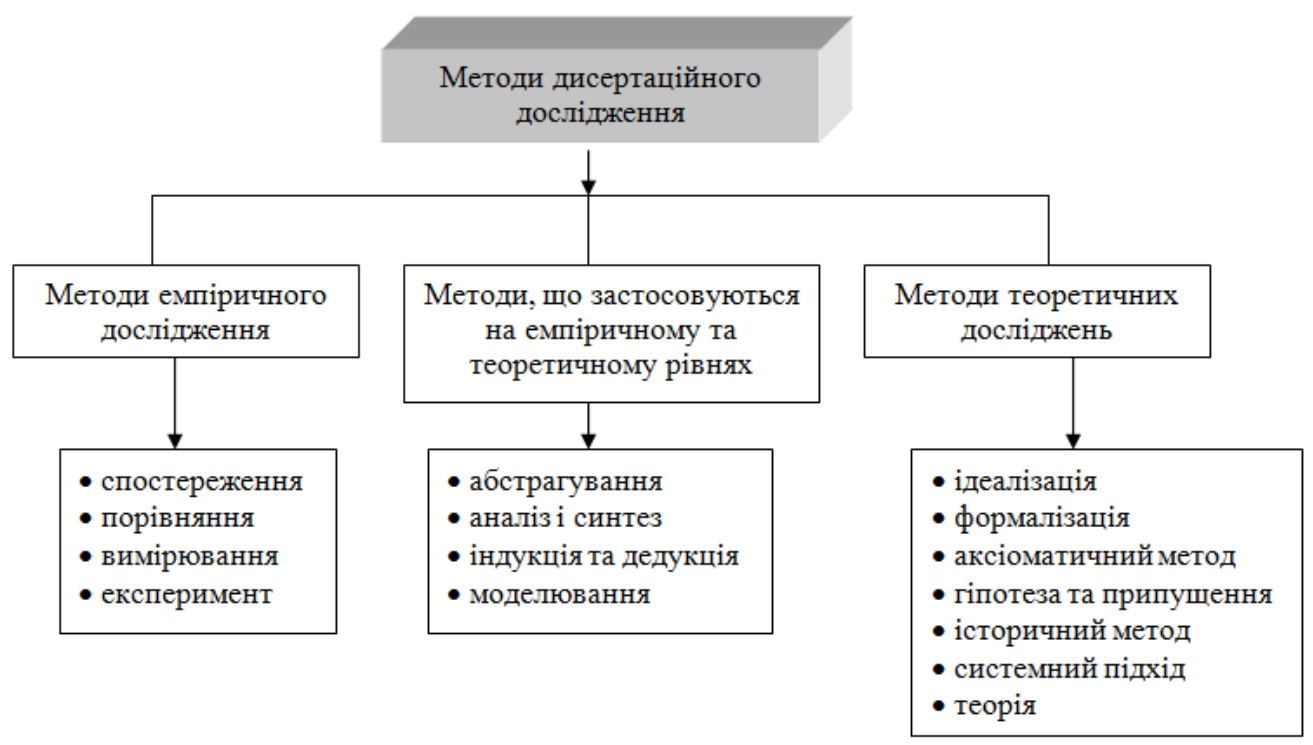

Джерело: [5,c. 9-14]

Логіка людської діяльності, в тому числі і науково-дослідної, відповідь на запитання «Як діяти?» ототожнює з певними законами і принципами, що і дають пряму безпосередню відповідь на це запитання.

Цей висновок дозволяє в теоретичному аспекті тлумачити методи як принципи (правила), тобто елементи знань. Звідси методи дослідження як наукова категорія - це принципи, яких дотримується дослідник. Іншими словами методи дослідження як наукова категорія - це способи реалізації вимог законів.

\section{Висновки}

Проведені дослідження свідчать, що поняття методу дослідження в літературних джерелах тлумачиться неоднозначно і продовжує залишатись дискусійним.

Першим кроком на шляху уточнення змісту цього поняття є доцільність розглядати його з двох боків:

1) як явище в практичній діяльності дослідника;

2) як наукову категорію.

Методи дослідження як явище - це практичні рухи, дії, операції і роботи на шляху до виявлення нових знань. Методи дослідження як наукова категорія - це конкретні принципи, як способи реалізації вимог відповідних законів, що регламентують рухи, дії, операції і роботи дослідника.

Офіційно оприлюднені в наукових джерелах варіанти класифікації методів сприймаються неоднозначно і потребують додаткових досліджень.

\section{Бібліографічні посилання}

Slipushko, O.M. (2007). Novyi slovnyk inshomovnykh sliv. Ukladannia i peredmova.. K.: Akonit (in Ukrainian).

Prokhorov, A.M. (1983). Sovetskiy entsiklopedicheskiy slovar. M.: Sov. Entsiklopedia (in Russian).

Kovaliova, G.V. (2005). Velykyi tlumachnyi slovnyk ukrainskoi movy. Kharkiv: Folio (in Ukrainian).

Surmin, Yu.P. (2006). Maysternia vchenogo: pidruchnyk dlia naukovtsia. K.: Navchalno-metodychnyi tsentr «Konsortsium z udoskonalennia menedzhment-osvity v Ukraini» (in Ukrainian).

Ponomarenko, A.A. (2011). Yak pidgotuvaty I zakhystyty dysertatsiiu na zdobuttia naukovogo stupenia. Metodychni porady. 5-e vydannia, vypravlene i dopovnene. K.: Vydavnytstvo «Toloka» (in Ukrainian).

Andriichuk, V.G. (2016). Sutnisnyi aspect metodologii naukovykh doslidzhen. Ekonomika APK. 7, 87-94 (in Ukrainian).

Ganin, V.I., Ganina, N.V., Gurova, K.D. (2008). Metodologiia sotsialno-ekonomichnykh doslidzhen. navch.posib. K.: «Tsentr uchbovoi literatury» (in Ukrainian).

Iermakov, O.Yu., Pogrischuk, G.B., Chornodon, V.I. (2009). Osnovy metodologii naukovykh doslidzhen: navch.posib. - Ternopil: «Pidruchnyky I posibnyky» (in Ukrainian).

Kandyba, A.M. (2007). Menedzhment naukovogo doslidzhennia: navch.posib. - K.: Agrarna nauka

Klymenko, M.O., Feschenko, V.P., Vozniuk, N.M. (2010). Osnovy ta metodologiia naukovykh doslidzhen: navch.posib. K.: Agrarna osvita (in Ukrainian).

Krushelnytska, O.V. (2009). Metodologiia ta organizatsiia naukovykh doslidzhen: navch.posib. K.: Kondor (in Ukrainian).

Mochernyi, S.V. (2001). Metodologiia ekonomichnykh doslidzhen. Lviv: Svit (in Ukrainian).

Tsekhmistrova, G.S. (2003). Osnovy naukovykh doslidzhen: navch. posib. K.: Vydavnychyi dim «Slovo» (in Ukrainian).

Galchynskyi, A.S. (2010). Ekonomichna metodologiia. Logika onovlennia: Kurs lektsii. K.: «ADEF Ukraina» (in Ukrainian).

Стаття надійшла до редакиії 5.09.2016 